BIOFARM

Jurnal Ilmiah Pertanian

ISSN Print: 0216-5430; ISSN Online: 2301-6442

Vol. 14, No. 2, Oktober 2018

\title{
Pemanfaatan Bawang Merah (Allium cepa L.) Sebagai Zat Pengatur Tumbuh Alami terhadap Pertumbuhan Bud Chip Tebu pada Berbagai Tingkat Waktu Rendaman
}

\author{
Utilization of Shallots (Allium cepa L.) as a Natural Growth Regulator for the \\ Growth of Sugarcane Bud Chip at Various Levels of Soaking Time
}

\author{
Saktiyono Sigit Tri Pamungkas* dan Rani Puspitasari \\ Politeknik LPP Yogyakarta \\ *Korespondensi Penulis: sakti@politeknik-Ipp.ac.id
}

\begin{abstract}
ABSTRAK
Penelitian ini bertujuan untuk mengetahui pengaruh lama perendaman ekstrak bawang merah (Allium cepa L.) sebagai zat pengatur tumbuh (ZPT) alami terhadap pertumbuhan bud chip tebu (Saccharum officinarum L.). Bibit tebu yang digunakan adalah varietas BL (Bulu Lawang). Parameter pengamatan yang diamati yaitu tinggi tanaman (cm), jumlah daun (helai), panjang akar terpanjang $(\mathrm{cm})$, saat tumbuh tunas (hst) dan persentase bud chip yang tumbuh. Penelitian ini dilakukan menggunakan Rancangan Acak Kelompok (RAK) non faktorial, yang terdiri dari 5 perlakuan dengan 3 kali ulangan sebagai blok, sehingga terdapat 15 unit percobaan. Masing-masing unit percobaan terdapat 3 ulangan tanaman sampel, sehingga total terdapat 45 tanaman sampel. Perlakuan tersebut terdiri dari yaitu W0 (Kontrol/tanpa perendaman), W1 (lama perendaman 1 jam), W2 (lama perendaman 2 jam), W3 (lama perendaman 3 jam) dan W4 (lama perendaman 4 jam). Hasil data yang diperoleh dianalisis menggunakan analisa ragam (anova) dengan signifikasi $95 \%$, apabila terdapat beda nyata dilanjutkan dengan uji lanjut Duncan Multiple Range Test (DMRT). Berdasarkan hasil penelitian ini menunjukkan bahwa terdapat beda nyata terhadap parameter tinggi tanaman $(\mathrm{cm})$ dan panjang akar terpanjang $(\mathrm{cm})$ akibat perendaman ZPT. Berdasarkan hasil penelitian lama perendaman kisaran satu sampai tiga jam menunjukkan hasil yang baik pada setiap parameter, tetapi hasil yang paling baik yaitu lama perendaman satu jam (W1) karena memiliki nilai paling tinggi untuk parameter tinggi tanaman $(\mathrm{cm})$ dan panjang akar terpanjang $(\mathrm{cm})$.
\end{abstract}

Kata kunci: tebu, zat pengatur tumbuh, ekstrak bawang merah, bud chip

\section{ABSTRACT}

The objectives of this research were to obtained effect of red onion (Allium cepa L.) extract as organic plant growth regulator to sugarcane (Saccharum officinarum L.) bud chip growth from Bululawang (BL) varieties. Parameter were observed of plant height $(\mathrm{cm})$, total of leaves, total of long roots $(\mathrm{cm})$, appearance of buds and percentaced of bud chip growth (\%). This research was design used non-factorial randomized block design (RBD) wich consisting of five treatment with three repeated. Experimental factor were longer of red onion extract soaked with comprised four levels that were W1 (control), W2 (2 hour soaked), W3 (3 hour soaked) and W4 (4 hour soaked). Obtained data was analyzed by $F$ test, wen significantly different then followed by DMRT with level 95\%. Statistics analysis result showed that soaked of red onion extract have been significant effect on plant height $(\mathrm{cm})$ and total of long roots $(\mathrm{cm})$. Overall result in DMRT test have been good for every parameters, but the best result was showed in W1 (2 hour soaked) treatment because it has the tallest plant and the longest roots.

Keywords: sugar cane, plant growth regulator, red onion extract, bud chip

\section{PENDAHULUAN}

Tebu (Saccharum officinarum L.) merupakan jenis tanaman rumput rumputan yang dibudidayakan sebagai tanaman penghasil gula. Tanaman ini sangat dibutuhkan sehingga kebutuhannya terus meningkat seiring dengan pertambahan jumlah penduduk. Namun peningkatan konsumsi gula belum dapat diimbangi oleh produksi gula dalam negeri. Gula merupakan salah satu bahan pokok ma- syarakat Indonesia dan mencapai swasembada gula konsumsi dengan produksi 2,715 juta ton dan luas areal 478.000 hektar. Penggunaan fungisida sintetik yang kurang bijaksana selain menimbulkan resistensi dan menyebabkan munculnya ras baru patogen juga berdampak terhadap kesehatan manusia dan mencemari ling-kungan, karena residunya yang sulit terurai di alam. Salah satu alternatif pengendalian yang relatif aman terhadap 
lingkungan dan manusia serta murah adalah pengendalian hayati. Upaya peningkatan produksi gula salah satunya adalah dengan penyediaan bibit unggul dan bermutu. Pemenuhan bibit ini diharapkan akan meningkatkan produktivitas dan kualitas tebu sehingga pada akhirnya mampu mendukung upaya swasembada gula nasional (Mulyono, 2011).

Permasalahan yang ada dalam memperbanyak tanaman secara vegetatif melalalui pembibitan menggunakan bud chip adalah sulitnya pembentukan akar. Salah satu upaya untuk mempercepat pertunasan dan tumbuh akar pada pada tanaman tebu adalah dengan pengunaan Zat Pengatur Tumbuh (ZPT). Penggunaan ZPT yang tepat akan berpengaruh baik terhadap pertumbuhan tanaman namun bila dalam jumlah yang terlalu banyak maka akan merugikan tanaman atau dapat meracuni tanaman. ZPT merupakan suatu zat pendorong pertumbuhan apabila diberikan dalam jumlah yang tepat. Sebaliknya bila diberikan dalam jumlah yang terlalu tinggi dari yang dibutuhkan tanaman maka akan menghambat proses metabolism tanaman (Salisbury dan Ross, 1995). Cara pemberian ZPT dapat dilakukan dengan berbagai cara, salah satunya dengan cara perendaman. Metode perendaman adalah metode praktis yang paling awal ditemukan dan sampai saat ini masih dipandang paling efektif (Wirartri, 2005). Salah satu tumbuhan yang dapat digunakan sebagai ZPT alami adalah bawang merah (ekstrak).

Nofrizal (2007) juga menyatakan bahwa ekstrak bawang merah ini mengandung auksin endogen yang dihasilkan dari umbi lapis. Umbi lapis ini didalamnya terdapat calon tunas sedangkan pada sisi luarnya terdapat lateral. Tunas-tunas muda pada bawang merah menghasilkan auksin alami berupa IAA (Indodole Acetid Acid). Auksin ini berperan penting dalam pertumbuhan tanaman, dimana perannya seperti pembesaran, pemanjangan dan pembelahan sel serta mempengaruhi metabolisme asam nukleat dan metabolisme tanaman (Lawalata, 2011). Berdasarkan hasil penelitian bahwa ekstrak bawang merah sebanyak $30 \%$ dari $300 \mathrm{ml}$ ekstrak ditambah dengan 1 liter air dapat meningkatkan daya kecambah pada benih kakao (Darojat et al, 2015). Umbi bawang merah juga terdapat vitamin B1 yang dapat merangsang pertumbuhan akar pada tanaman baru, tetapi hal ini paling baik digunakan apabila dikombinasikan dengan hormone perakaran yang lain (Anonim,2014).

Berdasarkan pemikiran tersebut, dapat dirumuskan permasalahan yang meliputi apakah ekstrak bawang merah sebagai ZPT alami dapat mempengaruhi pertumbuhan pada bud chip tebu melalui perendaman dan berapakah waktu perendaman konsentrasi ekstrak bawang merah sebagai ZPT alami yang efektif untuk meningkatkan pertumbuhan akar pada bud chip tebu.

\section{BAHAN DAN METODE}

Penelitian dilakukan di Greenhouse Budidaya Tanaman Perkebunan Politeknik LPP Yogyakarta, dari bulan Februari sampai dengan April 2018. Alat yang digunakan dalam penelitian ini adalah ayakan tanah, alat tulis, cangkul, pisau, ember, gembor, kamera, gelas ukur, kamera, alat-alat budidaya pada umumnya dan penggaris. Bahan digunakan dalam penelitian ini adalah media tanaman (tanah), air, bibit tebu bud chip varietas $\mathrm{BL}$ (bululawang), kertas label, plastik klip, ekstrak bawang merah, dan polybag (ukuran 17×20 $\mathrm{cm}$ ).

Penelitian ini dilakukan menggunakan Rancangan Acak Kelompok (RAK) non faktorial, yang terdiri dari 5 percobaan dengan 3 kali ulangan dan menggunakan 3 blok, sehingga terdapat 15 unit percobaan untuk setiap blok, sehingga total terdapat 45 tanaman sampel dengan perlakuan sebagai berikut: W0 (tanpa perendaman/kontrol), W1 (perendaman 1 jam), W2 (perendaman 2 jam), W3 (perendaman 3 jam) dan W4 (perendaman 4 jam). Parameter yang diamati adalah tinggi tanaman $(\mathrm{cm})$, panjang akar terpanjang $(\mathrm{cm})$, jumlah daun (helai), saat muncul tunas (hst) dan persentase bud chip hidup (\%). 
Data yang diperoleh dianalisis menggunakan uji $\mathrm{F}$ pada tingkat kepercayaan $95 \%$, apabila terdapat beda nyata dilakukan uji berganda Duncan (DMRT).

\section{HASIL DAN PEMBAHASAN}

Tabel 1. Hasil Analisa Ragam Pengaruh lama perendaman Ekstrak Bawang Merah (Allium Cepa L.) terhadap pertumbuhan bibit tanaman tebu (Saccharum Officinarum L.)

\begin{tabular}{|c|c|c|}
\hline No. & Variabel yang diamati & $\begin{array}{l}\text { Lama } \\
\text { Perendaman }\end{array}$ \\
\hline 1. & Tinggi tanaman $(\mathrm{cm})$ & $\mathrm{n}$ \\
\hline 2. & Jumlah Daun (helai) & tn \\
\hline 3. & $\begin{array}{l}\text { Panjang Akar } \\
\text { Terpanjang }(\mathrm{cm})\end{array}$ & $\mathrm{n}$ \\
\hline 4. & $\begin{array}{l}\text { Saat tumbuh tunas } \\
\text { (hari ke-) }\end{array}$ & tn \\
\hline 5. & $\begin{array}{l}\text { Persentasi bud chip } \\
\text { yang tumbuh }\end{array}$ & tn \\
\hline
\end{tabular}

tinggi tanaman dan panjang akar terpanjang, sedangkan pada parameter jumlah daun, saat tunas tumbuh dan persentase bud chip yang tumbuh menunjukkan hasil tidak beda nyata. Hasil analisa ragam dan uji lanjut yang dilakukan adalah sebagai berikut.

\section{Tinggi tanaman (cm)}

Hasil perendaman ekstrak bawang merah menunjukkan adanya pengaruh nyata terhadap tinggi tanaman bibit tebu. Berdasarkan uji DMRT, perlakuan W1 menunjukkan hasil rata-rata tinggi tanaman yang paling baik yaitu $78,756 \mathrm{~cm}$, sedangkan perlakuan $W 2$ yaitu $71,411 \mathrm{~cm}$, perlakuan W3 yaitu 67,878 $\mathrm{cm}$, perlakuan W4 yaitu $62,067 \mathrm{~cm}$, dan perlakuan WO yaitu $56,622 \mathrm{~cm}$. Dalam konsentrasi yang rendah auksin akan dapat bekerja secara optimal, sedangkan dalam konsentrasi yang tinggi justru akan menghambat pertumbuhan tanaman (Dwijasaputro, 2004).

Berdasarkan hasil analisa ragam (anova), terdapat beda nyata pada parameter

Tabel 2. Hasil Analisa DMRT Pengaruh Lama Perendaman Ekstrak Bawang Merah (Allium Cepa L.) Terhadap Pertumbuhan Bibit Tanaman Tebu (Saccharum officinarum L.)

\begin{tabular}{cccccc}
\hline Perlakuan & $\begin{array}{c}\text { Tinggi } \\
\text { Tanaman } \\
\text { (cm) }\end{array}$ & $\begin{array}{c}\text { Jumlah Daun } \\
\text { (helai) }\end{array}$ & $\begin{array}{c}\text { Panjang } \\
\text { Akar } \\
\text { Terpanjang } \\
\text { (cm) }\end{array}$ & $\begin{array}{c}\text { Saat tunas } \\
\text { tumbuh } \\
\text { (hst) }\end{array}$ & $\begin{array}{c}\text { Bud chip yang } \\
\text { tumbuh }\end{array}$ \\
\hline W0 & $56,622 \mathrm{a}$ & 4,00 & $28,44 \mathrm{a}$ & 8,11 & 0,89 \\
W1 & $78,756 \mathrm{~b}$ & 4,78 & $39,44 \mathrm{~b}$ & 9,00 & 1,00 \\
W2 & $71,411 \mathrm{ab}$ & 4,67 & $33,67 \mathrm{ab}$ & 9,00 & 1,00 \\
W3 & $67,878 \mathrm{ab}$ & 4,67 & $28,44 \mathrm{a}$ & 9,00 & 1,00 \\
W4 & $62,067 \mathrm{a}$ & 4,00 & $27,22 \mathrm{a}$ & 8,00 & 0,89 \\
\hline F hit & 0,475 & 0,452 & 1,505 & 0,593 & 0,487 \\
\hline
\end{tabular}

Angka yang diikuti oleh huruf yang sama tidak berbeda nyata berdasarka uji DMRT $5 \%$.

Perendaman satu jam bibit tanaman tebu dapat tumbuh dengan baik, diduga konsentrasi auksin endogen yang masuk melalui transpor zat pengatur tumbuh (zpt) optimal, sehingga peran auksin untuk pembelahan sel-sel meristem pada jaringan muda akan optimal. Berdasarkan system transpor hormon pada tanaman, perendaman satu jam (W1) memiliki jumlah auksin yang lebih sedikit dibandingkan dengan perendaman dua sampai dengan empat jam, namun pada perlakuan W2, W3 dan W4 memiliki tinggi tanaman yang lebih rendah, hal ini diduga karena lamanya perendaman sehingga auk- sin eksogen dalam jumlah tinggi yang mengakibatkan kerja hormon tanaman terganggu. Kelebihan zpt juga akan mengakibatkan terganggunya reaksi enzimatis dalam sel (Siswanto, 2010). Lebih lanjut dikatakan oleh Adelina (2009), bahwa perendaman zat tertentu untuk memacu pertumbuhan bibit tanaman yang terlalu lama dapat membuat kemampuan memanjang sel melalui mekanisme seluler menurun (Adelina, 2009). Auksin menyebabkan sel didalam batang mengeluarkan ion hidrogen ke seliling dinding sel yang kemudian menurunkan $\mathrm{pH}$ dan mengakibatkan mengendornya dinding sel dan 
pertumbuhan tanaman dengan cepat (Siswanto, 2010). Auksin yang diserap oleh jaringan tanaman akan mengaktifkan energi cadangan makanan dan meningkatkan pembelahan sel dan pemanjangan sel yang pada akhirnya membentuk pemanjangan batang (Shiddiqi, 2012).

\section{Jumlah daun (helai)}

Berdasarkan Uji lanjut dengan menggunakan DMRT menunjukkan tidak beda nyata terhadap jumlah daun. Hasil tersebut menunjukan rata-rata nilai tertinggi di perlakuan perendaman satu jam (W1) 4,78 helai, W2 adalah 4,67 helai, rata-rata nilai W3 adalah 4,67 helai, rata-rata nilai W0 4,00 helai dan rata-rata nilai W4 adalah 4,00 helai. Walaupun tidak nyata, tetapi rata-rata nilai tertinggi terdapat pada perlakuan dengan perendaman satu jam (W1), diduga perendaman dengan waktu satu jam merupakan waktu optimal agar auksin eksogen dapat diserap dengan baik oleh bud chip, sehingga hormon auksin yang berada didalam ekstrak bawang merah juga berkerja dengan baik.

Dalam kaitannya fungsi zpt, hormon sitokinin juga merupakan zpt yang mempengaruhi munculnya tunas yang pada proses diferensialnya akan menjadi daun. Kehadiran auksin akan mempengaruhi kerja sitokinin. Apabila auksin dalam konsentrasi yang tepat, maka transpor sitokinin sesuai fungsinya untuk menginisiasi tunas akan muncul. Auksin berperan dalam proses pembelahan sel, sehingga pada saat proses diferensiasi sel menjadi jaringan daun sitokinin akan mempengaruhi proses tersebut. Apabila jumlah auksin terlalu tinggi, maka proses diferensiasi daun akan terhambat, karena kemampuan sel meristem membelah lebih tinggi daripada proses diferensiasi menjadi tunas atau daun (celuler growth overlaping). Sitokinin endogen berfungsi untuk merangsang pertumbuhan daun, apa bila auksin yang berada di dalam tanaman terlalu banyak maka proses pertumbuhan daun tidak ada beda nyata. Dalam kondisi auksin yang terlalu banyak, sitokinin tidak akan bisa aktif atau bekerja secara optimal, sehingga pertumbuhan daun tidak dapat optimal (Abidin, 2009).

\section{Panjang akar terpanjang $(\mathrm{cm})$}

Berdasarkan uji lanjut dengan menggunakan DMRT dengan taraf $5 \%$ menunjukkan adanya beda nyata terhadap panjang akar terpanjang. Berdasarkan anova, perlakuan W1 menunjukkan hasil rata-rata panjang akar terpanjang yang paling baik yaitu $39,44 \mathrm{~cm}$, sedangkan nilai rata-rata paling rendah pada perlakuan $W 4$ yaitu $27,22 \mathrm{~cm}$. Nilai rata-rata W2 $33,67 \mathrm{~cm}$, W0 (kontrol) yaitu $28,44 \mathrm{~cm}$, dan W3 yaitu $28,44 \mathrm{~cm}$. Ekstrak bawang merah mengandung akusin yang dapat memacu pembelahan sel pada batang bibit tanaman tebu. Auksin yang ditambahkan melalui ekstrak bawang merah mampu merangsang pertumbuhan akar dan tunas (Rahayu dan Berlian, 1999).

Mekanisme kerja auksin akan mempengaruhi pemanjangan sel-sel akar pada tanaman. Auksin mempengaruhi pelenturan dinding sel, akibatnya sel tumbuhan kemudian memanjang akibat air masuk secara osmosis. Selain memacu pemanjangan sel yang menyebabkan pemanjangan akar dan batang, peranan auksin lainnya adalah adanya kombinasi antara auksin dan giberelin akan memacu perkembangan jaringan pembuluh dan mendorong pembelahan sel pada kambium serta proses diferensasi sel (Rusmin, 2011). Pada perlakuan lama perendaman satu jam (W1) pertumbuhan panjang akar dapat tumbuh dengan baik. Pada perlakuan perendaman empat jam (W4) memiliki nilai rata-rata panjang akar terpanjang terendah yaitu $27,22 \mathrm{~cm}$. Pengaruh rangsangan auksin terhadap jaringan berbeda-beda, rangsangan paling kuat terutama terhadap sel-sel meristem apikal batang. Pada kadar yang terlalu tinggi, auksin lebih bersifat menghambat dari pada memacu atau merangsang pertumbuhan tanaman.

Lama perendaman yang terlalu lama menyebabkan terjadi penurunan panjang akar, akibat peningkatan lama perendaman ZPT ekstrak bawang merah, sehingga apabila kadar auksin dinaikkan maka pertumbuhan panjang akar akan menurun (Abidin, 
1990). Selain hal tersebut, diduga pada proses penelitian di greenhouse perlakuan W4 tidak ternaungi dengan baik, sehingga intensitas cahaya yang tinggi akan merusak hormon auksin. Bibit yang di letakan pada kondisi intensitas cahaya matahari yang tinggi pertumbuhan sel-sel meristematik akan terhambat. Selain itu, suhu yang tinggi akan mempengaruhi distribusi auksin yang tidak merata dalam batang dan akar, sehingga pembesaran sel meristem tidak di imbangi dengan pembengkakan atau pemanjangan jaringan

\section{Saat tumbuh tunas (hst)}

Berdasarkan uji lanjut dengan menggunakan DMRT dengan taraf $5 \%$ menunjukkan tidak beda nyata terhadap variabel saat tumbuh tunas (hst). Berdasarkan uji DMRT menunjukkan tidak ada beda nyata pada variabel saat tumbuh tunas. Hasil tersebut menunjukan rata-rata nilai tertinggi di perlakuan perendaman satu jam (W1), perendaman dua jam (W2) dan perendaman tiga jam (W3) yaitu 9,00 (hari ke-9) ekstrak bawang merah dan rata-rata nilai terendah adalah W4 (perendaman empat jam) yaitu 8,00 (hari ke-8). Rata-rata nilai WO adalah 8,11 hari , rata-rata nilai $W 1$ adalah 9,00 hari, rata-rata nilai W2 adalah 9,00 hari, rata-rata nilai W3 adalah 9,00 hari dan rata-rata nilai W4 adalah 8,00 hari.

Pertumbuhan tunas pada tanaman sangat dipengaruhi oleh hormon sitokinin. Sitokinin adalah suatu zat pengatur tumbuh yang ada didalam tubuh suatu tanaman, hormon sitokinin pada suatu tanaman berfungsi untuk proses pertumbuhan tunas, yang kemudian merangsang pertumbuhan daun. Salah satu fungsi utama auksin adalah sebagai suatu sistem yang dinamakan dominansi apikal. Dominansi apikal adalah hambatan pertumbuhan sebagian atau keseluruhan tunas lateral karena adanya tunas apikal. Tunas apikal ini terdapat di ujung tanaman. Pada penelitian ini bibit yang digunakan adalah bud chips yang telah di potong bagian apikal tebunya. Dominansi apikal terjadi karena aktifitas atau transpor auksin ke bagian pucuk batang berlebih sehingga tunas samping atau tunas pada nodus tetap dorman, hal ini yang menyebabkan tunas tumbuh lebih lama (Dewi, 2008). Lebih lanjut Dewi (2008) menyatakan bahwa auksin yang diproduksi oleh ujung tunas apikal berdifusi kebawah sesuai gaya gravitasi, sehingga pemotongan tunas apikal menyebabkan tunas lateral tumbuh. Tunas lateral ini akan tumbuh karena dipicu diproduksinya auksin endogen di ujung tunas lateral dan nodus. Oleh karena produksi auksin hingga transpor membutuhkan waktu, maka munculnya tunas menjadi lebih lama. Kaitannya dengan sitokinin, apabila jumlah transpor auksin yang diperlukan pertumbuhan tanaman cukup, maka proses diferensiasi sel-sel meristem akan terjadi akibat rangsangan sitokinin endogen.

\section{Persentase bud chip tumbuh (\%)}

Berdasarkan Uji lanjut dengan menggunakan DMRT dengan taraf $5 \%$ menunjukkan tidak beda nyata terhadap persentase bud chip yang tumbuh. Berdasarkan uji lanjut yang menggunakan DMRT menunjukkan tidak ada beda nyata pada variabel bud chip yang tumbuh (jumlah yang tumbuh). Hasil tersebut menunjukan rata-rata nilai tertinggi di perlakuan perendaman satu jam (W1), perendaman dua jam (W2) dan perendaman tiga jam (W3) yaitu 1,00 ekstrak bawang merah dan rata-rata nilai terendah adalah $\mathrm{W} 4$ (perendaman empat jam). Rata-rata nilai WO adalah 0,89 , rata-rata nilai $\mathrm{W} 1$ adalah 1,00 , rata-rata nilai $\mathrm{W} 2$ adalah 1,00 , rata-rata nilai W3 adalah 1,00 dan rata-rata nilai W4 adalah 0.89 . Persentase bud chip yang tumbuh pada perlakuan W1, W2 dan W3 yaitu $100 \%$ dengan masing-masing nilai rata-rata 1,00 , sedangkan persentase bud chip yang tumbuh pada perlakuan W0 dan W4 yaitu $89 \%$ dengan masing-masing nilai rata-rata 0,89 . Lama perendaman W4 memiliki nilai rata-rata yang paling redah yaitu 0,89 .

Pada kadar yang terlalu tinggi, auksin lebih bersifat menghambat pertumbuhan tanaman dari pada memacu pertumbuhan tanaman. Pengaruh auksin terhadap perkembangan sel-sel menunjukkan indikasi bahwa auksin dapat menaikkan tekanan osmotik, meningkatkan sintesis protein, dan melunak- 
kan dinding sel yang diikuti menurunnya tekanan dinding sel yang disertai dengan kenaikkan volume sel (Abidin, 1982). Pernyataan tersebut sesuai dengan hasil penelitian ini, bahwa kadar auksin yang tinggi akan menurunkan tekanan osmotik. Meningkatnya sintesa protein, tetapi tidak diikuti peningkatan tekanan osmotik melibatkan sel-sel tidak berkembang dengan optimal, hal ini menyebabkan kematian sel-sel meristem. Pemberian auksin pada tanaman hendaknya pada lama perendaman yang optimal yaitu pada lama peredaman yang mampu diterima baik dengan tanaman. Berdasarkan penelitian perendaman yang paling optimal yaitu kisaran antara satu sampai dengan tiga jam. Setiap tanaman memerlukan kondisi lingkungan yang sesuai untuk tempat mereka tumbuh. Pada lingkungan yang sesuai maka tanaman dapat tumbuh dengan baik. Kondisi lingkungan tempat tanaman berada selalu mengalami perubahan.

Perubahan yang terjadi mungkin saja masih berada dalam batas toleransi tanaman tersebut, tetapi seringkali tanaman mengalami perubahan lingkungan yang dapat menyebabkan menurunnya produk-tivitas dan bahkan kematian tanaman. Hal ini menunjukkan bahwa setiap tanaman memiliki faktor pembatas dan daya toleransi terhadap lingkungan. Pertumbuhan yang baik bagi tanaman dapat dipengaruhi dari faktor internal dan faktok eksternal. Faktor internal yaitu faktor yang berasal dari bibit tanaman itu sendiri, sedangkan faktor dari luar yaitu faktor yang mempengaruhi bibit dari luar. Misalnya faktor internal yaitu gen yang ada didalam tanaman itu sendiri sedangkan faktor eksternal kondisi lingkungan yang tidak mendukung pertumbuhan dan perkembangan bagian tanaman seperti kekurangan dan kelebihan unsur hara, kekurangan dan kelebihan air, suhu yang terlalu rendah atau terlalu tinggi, kurangnya cahaya matahari, kelembaban. Bila tanaman kekurangan cahaya maka proses fotosintesis menjadi rendah, akibatnya hasil fotosintesis dapat terombak oleh proses respirasi, cadangan makanan berkurang sehingga pertumbuhan tanaman terhambat. (Widiastoety et al., 2000).

\section{KESIMPULAN}

1. Ekstrak bawang merah sebagai ZPT alami berpengaruh nyata pada parameter tinggi tanaman dan panjang akar terpanjang.

2. Ekstrak bawang merah sebagai ZPT alami tidak berpengaruh nyata pada parameter jumlah daun, saat muncul tunas dan persentase bud chip yang hidup.

3. Konsentrasi ekstrak bawang merah sebagai ZPT alami yang efektif adalah pada lama perendaman satu sampai tiga jam.

\section{DAFTAR PUSTAKA}

Abidin, Z. 1993. Dasar-Dasar Pengetahuan Tentang Zat Pengatur Tumbuh. Angkasa, Bandung.

Adelina, E. 2009. Pemotongan dan Pemberian Auksin Pada Kecambah Kakao. J. Agroland Vol. 11 No. 3 : 255260.

Darojat, M. K., R. S. Resmisari, dan A. Nasichuddin. 2015. Pengaruh konsentrasi dan lama perendaman ekstrak bawang merah (Allium cepa L.) terhadap viabilitas benih kakao (Theobroma cacao L.). Jurnal Penelitian Universitas Islam Negeri Maulana Malik Ibrahim. $7 \mathrm{hlm}$.

Dewi, I.R. 2008. Peranan dan Fungsi Fitohormon bagi Pertumbuhan Tanaman. Skripsi. Fakultas Pertanian. Universitas Padjadjaran, Bandung.

Dwijasaputro. 2004. Fisiologis Tumbuhan. Gadjah Mada Press, Yogyakarta.

Heddy, dan Zaenal Abidin. 1996. Biologi Jilid III. Erlangga, Jakarta.

Lawalata, Imelda Jeannete. 2011. Pemberian Beberapa Komninasi ZPT terhadap Regenerasi Tanaman Gloxinia (Siningia speciaso) dari Eksplan Batang dan Daun Secara In Vitro. Exp.Life Sci, 1(2):83-87. 
Mulyono, D. 2010. Pengaruh Zat Pengatur Tumbuh Auksin : Indole Butiric Acid (lba) dan Sitokinin : Benzil Amino Purine (Bap) dan Kinetin Dalam Elongasi Pertunasan Gaharu (Aquilaria beccariana). Pusat Teknologi Produksi Pertanian-BPPT.

Nofrizal, M. 2007. Pemberian Ekstrak Bawang Merah, Liquinox Start, NAA, Rooton F Untuk Aklimatisasi Stek Mini Pule Pandak (Rauvolifia serpentine Benth) Hasil Kultur In Vitro. Skripsi. Fakultas Kehutanan Institut Pertanian Bogor.

Rahayu, E, dan Berlian, N. V. A. 1999. Bawang Merah. Penebar Swadaya, Jakarta.

Rusmin, D. 2011. Pengaruh Pemberian GA Pada Berbagai Konsentrasi dan Lama Inbibisi. Jurnal.

Shiddiqi. U. A., Murniati, Sukemi. 2012. Pengaruh Pemberian Zat Pengatur Tumbuh Terhadap Pertumbuhan Bibit Stum Mata Tidur Tanaman Karet
(Hevea brasilliensis). Jurnal. Fakultas Pertanian Universitas Riau.

Rosanty, Ratna dan Erliandi. 2015. Pengaruh Komposisi Media Tanam dan Lama Perendaman Auksin Terhadap Bibit Tebu Teknik Bud chip. Vol 3, No.1 : 378-389.

Salisbury, B. F. dan C. W. Ross. 1995. Fisiologi Tanaman Tebu. ITB, Bandung.

Siswanto, U. Purwanto dan Y. Widiyastuti. 2008. Respon Piper retrofraction Vahl. Terhadap Aplikasi Esktrak Bawang Merah dan Media. Tumbuhan Obat Indonesia, 1(1):1-10.

Wirartri, N. 2005. Pengaruh Cara Pemberian Rootone $\mathrm{F}$ dan Jenis Stek Terhadap Induksi Akar Stek Gmelina (Gmelina Arborea Linn). Institut Pertanian Bogor.

Anonim. 2014. Plant Hormones and Thiamine (Vitamin B1). http://www.quickgrow.com/gardening _articles/plant_hormones.html. 